\title{
UNSATURATED FISH ASSEMBLAGES IN RIVERS OF NORTH-WESTERN FRANCE : POTENTIAL CONSEQUENCES FOR SPECIES INTRODUCTIONS.
}

\author{
D. BELKESSAM (1), T. OBERDORFF $(1,2)^{\star}$, B. HUGUENY (3)
}

(1) Muséum National d'Histoire Naturelle, Laboratoire d'lchtyologie Générale et Appliquée, 43 rue Cuvier, 75231 Paris Cedex 5, France.

(2) Conseil Supérieur de la Pêche, Délégation Régionale de Compiègne, 3 rue Sainte-Marie, 60200 Compiègne, France.

(3) Antenne ORSTOM, Laboratoire d'Ecologie des Eaux Douces, Université Claude Bernard Lyon I, 43 boulevard du 11 novembre 1918, 69622 Villeurbanne Cedex, France.

\begin{abstract}
Introductions of freshwater fish into French rivers have been carried out with increasing frequency in the last decades. Thus, the potential impact of these introductions is of major concern for biologists and fishery managers. Knowledge of the degree of saturation of a community provides an important basis for understanding how the community reacts or will react to the introduction of new species. In this paper, we compare local and regional freshwater fish species richness in similar sizes tributaries and coastal rivers located in the same biogeographic region (North-Western France). We show 1) that species richness is greater for tributaries than for coastal rivers on both local (station) and regional (catchment) scales, and 2) that, whatever the rivers studied (tributaries or coastal rivers), there is a significant, positive linear relationship between local species richness and regional species richness. These findings suggest that local, and probably regional, freshwater fish communities in North-Western French rivers are unsaturated and thus, that major impacts on the community, such as short-term extinctions, are not to be expected. However, competition for food and space, predation, introduction of exotic parasites and diseases, could also affect some native species.
\end{abstract}

Key-words : species richness, fish assemblages, insaturation, local richness, regional richness, species introductions.

\section{INSATURATION DES PEUPLEMENTS PISCICOLES DANS LES COURS D'EAU FRANÇAIS DU NORD-OUEST : CONSÉQUENCES POTENTIELLES POUR LES INTRODUCTIONS D'ESPĖCES.}

\section{RÉSUMÉ}

Evaluer les conséquences des introductions d'espèces dans les cours d'eau reste difficile, car il est généralement reconnu que l'espèce introduite et la communauté réceptrice ne peuvent être étudiées séparément et que les conséquences liées à l'introduction de l'espèce sont susceptibles de se manifester à différents niveaux d'organisation écologique. A l'échelle des communautés piscicoles, la première question à se poser afin d'aborder le problème des introductions concerne leur degré de saturation ; en d'autres termes : jusqu'à combien d'espèces peut supporter un écosystème ? Bien que non suffisante, la réponse à cette question permettra de savoir si oui ou non le milieu est potentiellement colonisable.

\footnotetext{
* Corresponding author, auteur pour correspondance.
} 
Dans cet article, en se replaçant dans les perspectives théoriques générées par la biogéographie insulaire, nous comparons, à deux échelles spatiales que sont le bassin versant et la station, la richesse en espèces de fleuves côtiers et d'affluents de tailles similaires et situés dans une même région biogéographique. Nous montrons 1) qu'à l'échelle du bassin versant, la richesse en espèces des fleuves côtiers est inférieure à la richesse en espèces des affluents (richesse régionale) ; 2) qu'à l'échelle de la station, la richesse en espèces des fleuves côtiers est inférieure à la richesse en espèces des affluents (richesse locale) ; 3) qu'il existe une relation linéaire positive entre la richesse locale et la richesse régionale et cela quel que soit le type de cours d'eau considéré (affluents ou fleuves côtiers). Ainsi, il est permis de supposer qu'à l'échelle locale le milieu reste insaturé en espèces. Des effets importants sur la structuration des communautés, tels que des extinctions à court terme, sont donc peu probables. Néanmoins, cela ne veut pas dire que toute introduction irréfléchie sera sans conséquence sur les espèces résidantes. En effet, la prédation, la compétition pour l'espace et l'alimentation, l'introduction de parasites ou de maladies exotiques sont également susceptibles d'engendrer des effets délétères sur certaines espèces autochtones.

Mots-clés : richesse en espèces, peuplements piscicoles, insaturation, richesse locale, richesse régionale, introductions d'espèces.

\section{INTRODUCTION}

The introduction of fishes into European rivers began with the carp (Cyprinus carpio L.) during the Roman period and continued until the second part of the nineteenth century (BALON, 1974). The number of introduced species has increased over the years, especially since the beginning of the twentieth century. The species most frequently introduced in Europe are cyprinids, followed by salmonids and coregonids (HOLCIK, 1991).

The impact of species introduction into different ecosystems has been extensively documented throughout the world and many authors have commented on the difficulty of documenting the specific role of introduced species on native communities, particularly in freshwater fish communities (ARTHINGTON, 1991). However, it is widely agreed that the introduction of fish usually has a damaging effect on the receiving aquatic ecosystem and its indigenous fish fauna (HERBOLD and MOYLE, 1986 ; BROWN, 1989 ; BIANCO, 1990 ; HOLCIK, 1991 ; ELVIRA, 1995). Nevertheless, there is a lack of any valid evaluation of introduction experiments based on thorough ecological analysis (HOLCIK, 1991). In France, early publications which called attention to fish introductions, are those of CESTAS (1992) and KEITH et al. (1992). These publications essentially compile lists of fish transfers and provide very global analyses of the risks of introductions. One way for highlighting possible effects of introduced species on natural fish communities is to evaluate the degree of saturation in a given community. In a saturated community, a new (introduced) species must either go extinct or cause the extinction of another species (which the introduced species then replaces). Conversely, in a nonsaturated community, introduction of new species may be successful and cause no systematic extermination of existing species (PIANKA, 1983). CORNELL (1985) has devised a simple test to check for community saturation. If local species richness shows no tendency to reach a clear upper limit in regions with the highest species richness, but rather increases proportionately with regional richness, then local communities are presumably not saturated. Another important point is to assess the effects of introduced species at the regional scale (the term regional refers to the spatial scale at which biogeographic processes predominate). A positive relationship between river size and total number of resident fish species has been demonstrated in many cases, suggesting that, in some way, river size sets a limit for the number of species supported by a river (HUGUENY, 1989 ; WELCOMME, 1990 ; OBERDORFF et al., 1995). There are two main, non-exclusive, hypotheses to explain the species-area relationship : 1) area-dependent extinction rates, which form part of the theory of island biogeography (MC ARTHUR and WILSON, 1963, 1967) and 2) the habitat diversity hypothesis (MC ARTHUR and WILSON, 1967). According to the first hypothesis, the probability of extinction of a species increases as island size decreases, due to a decrease in total population size. The second hypothesis suggests that larger areas contain a larger array of habitat 
configurations and food resources, thereby providing more niches and supporting more species. Unfortunately, it is likely that in most insular systems these processes are together and their effects are mingled. To disentangle these two hypotheses, HUGUENY (1989) suggests that, in the light of the insular theory, two kinds of rivers must be considered : tributaries and fully isolated rivers (e.g. coastal rivers). Tributaries are similar to mainland areas since they have connections with other sections of the catchment area and can be colonized freely from surrounding parts of the river, in the same way that a mainland area can be colonized from its neighbourhood. Consequently there should be a larger number of species in a tributary than in a fully isolated river (e.g. coastal river) of similar size (HUGUENY, 1989 ; OBERDORFF et al., 1997) because extinction rates are not balanced by immigration. Conversely, under the habitat diversity hypothesis the same number of species is expected in the two kinds of similar size rivers (tributaries and coastal rivers).

In this paper, we address three primary questions : (i) at the catchment scale (regional scale), are there more species in tributaries than in comparable coastal rivers ? (ii) at the local scale (station scale), are there more species in tributaries than in comparable coastal rivers ? (iii) for the complete data set (tributaries and coastal rivers), is there a positive linear relationship between local and regional species richness ? Consequences of the results for the management of introduced species will be emphasized.

\section{MATERIAL AND METHODS}

\section{Data source}

Two main conditions have been respected to make the test valid:1) tributaries and coastal rivers studied were similar in size ; 2) assessment was carried out in geographic areas that were homogeneous with respect to a combination of environmental characteristics,

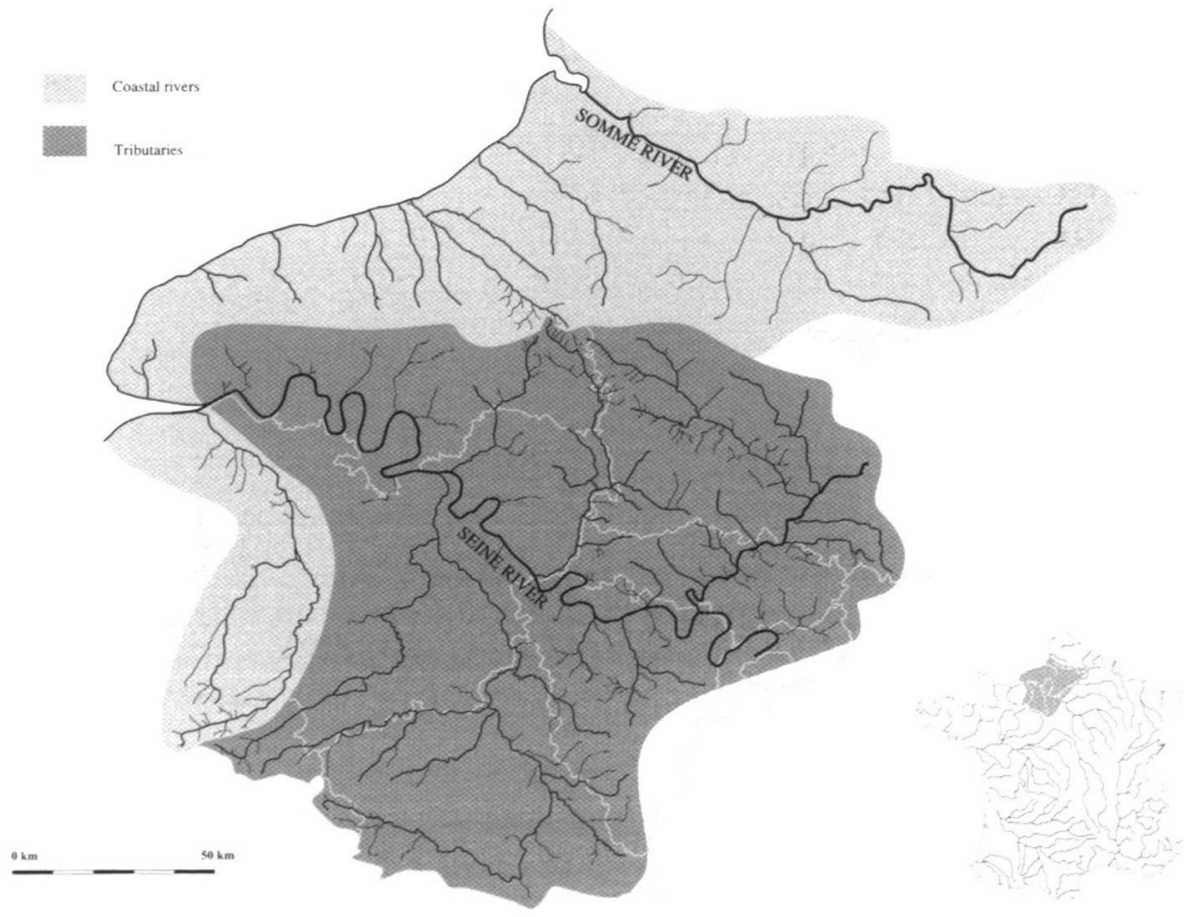

Figure 1

Area studied and its location in France.

Figure 1

Région étudiée et sa localisation en France. 
including climate, physiography, soils and vegetation in order to avoid potential influence of these factors on species richness (OMERNIK, 1987 ; HUGHES et al., 1987 ; HUGHES and LARSEN, 1988 ; WHITTIER et al., 1988). With this aim, we limited our investigation to rivers belonging to a same biogeographical unit (Seine-Normandie Basin ; region IID, a ring of upper cretaceous, auréole de crétacé supérieun as defined by DUPIAS and REY, 1985 (Figure 1).

We used two extensive data sets representing two different spatial scales. The first was a set of 10 tributaries and 11 coastal rivers (catchment scale) (Table 1). The second was a set of 17 (sampling) stations in tributaries and 20 (sampling) stations in coastal rivers (station scale) (Table II).

\section{Table I}

TSADB : total surface area of the drainage basin ; RSR : regional species richness (basin richness). Only native species are considered. Estuarine species are omitted.

\section{Tableau 1}

TSADB : surface totale du bassin versant ; RSR : richesse totale en espèces du bassin (échelle régionale). Seules les espèces autochtones sont considérées. Les espèces estuariennes sont exclues.

COASTAL RIVERS

RISLES

DURDENT

SAANE

YERES

SCIE

BRESLE

LEZARDE

ARQUES

SOMME

VALMONT

AUTHIE

TRIBUTARIES

EPTE

THERAIN

AUSTREBERTHE

CAILLY

ANDELLE

VAUCOULEUR

EURE

BRECHE

VIOSNE

RANCON
TSADB (square km)

RSR

1660

44

117

64

50

460

46

660

6000

45

750

13

6

6

4

6

14

6

12

16

4

7

TSADB (square $\mathbf{k m}$ ) RSR

1336

16

990

32

14

4

90

6

286

135

14

13

5238

19

245

14

110

12 
Table II

SADB : surface area of the drainage basin ; LSR : local species richness (local scale) ; RSR : regional species richness (basin richness). Successfully introduced species are included. Estuarine species are omitted.

\section{Tableau II}

SADB : superficie du bassin versant drainé ; LSR : richesse en espèces de la station léchelle locale) ; RSR : richesse régionale (richesse totale du bassin). Les espèces introduites acclimatées sont incluses. Les espèces estuariennes sont exclues.

\begin{tabular}{|c|c|c|c|}
\hline COASTAL RIVERS & SADB (square km) & LSR & RSR \\
\hline LEZARDE & 10 & 4 & 7 \\
\hline LEZARDE & 29 & 6 & 7 \\
\hline RISLE & 295 & 6 & 17 \\
\hline RISLE & 565 & 9 & 17 \\
\hline CHARENTONNE & 360 & 7 & 17 \\
\hline CHARENTONNE & 372 & 8 & 17 \\
\hline GUIEL & 57 & 5 & 17 \\
\hline DURDENT & 20 & 5 & 7 \\
\hline DURDENT & 25 & 4 & 7 \\
\hline SAÂNE & 10 & 5 & 7 \\
\hline VIENNE & 18 & 4 & 7 \\
\hline SCIE & 61 & 4 & 7 \\
\hline VARENNE & 25 & 4 & 15 \\
\hline VARENNE & 131 & 6 & 15 \\
\hline VARENNE & 152 & 8 & 15 \\
\hline YERES & 40 & 4 & 5 \\
\hline YERES & 70 & 5 & 5 \\
\hline BRESLE & 89 & 5 & 17 \\
\hline BRESLE & 390 & 6 & 17 \\
\hline BRESLE & 502 & 6 & 17 \\
\hline TRIBUTARIES & SADB (square km) & LSR & RSR \\
\hline BRECHE & 92 & 9 & 30 \\
\hline THERAIN & 13 & 4 & 30 \\
\hline PETIT THERAIN & 41 & 6 & 30 \\
\hline RU ONS BRAY & 3 & 6 & 30 \\
\hline AVELON & 62 & 5 & 30 \\
\hline VIOSNE & 71 & 13 & 30 \\
\hline VAUCOULEUR & 24 & 6 & 30 \\
\hline EPTE & 140 & 9 & 30 \\
\hline EPTE & 228 & 10 & 30 \\
\hline MESANGUEVILLE & 30 & 8 & 30 \\
\hline ANDELLE & 100 & 11 & 30 \\
\hline CREVON & 8 & 5 & 30 \\
\hline CREVON & 17 & 5 & 30 \\
\hline AVRE & 400 & 9 & 30 \\
\hline ITON & 276 & 8 & 30 \\
\hline CAILLY & 11 & 5 & 30 \\
\hline AUSTREBHERTE & 8 & 4 & 30 \\
\hline
\end{tabular}


Values for the richness of native freshwater fish species (estuarine species were omitted) from entire drainage basins (number of species in drainage basin) were extracted from the database managed by the Conseil Supérieur de la Pêche (Banque Hydrobiologique et Piscicole) and covering 10 years of survey. Consequently, these values can be considered as quite reliable. The status of each freshwater fish species (whether native or introduced) was obtained from BELLIARD, 1994. Data for the richness of local freshwater fish species (number of species at a site, including successfully introduced species) were collected between 1989 and 1991 . Sites were sampled by electrofishing, during low flow periods, and using standardized methods. This procedure allows a comparison between sites.

The catchment area for each drainage basin and each site was measured with a digital planimeter on a $1: 500,000$ scale map of the Seine Basin provided by the Agence de l'Eau Seine-Normandie.

\section{Statistical methods}

We performed regressions using the method of least squares. We used analysis of covariance (SOKAL and ROHLF, 1981) to examine patterns of variation of number of freshwater fish present among tributaries and coastal rivers (coded as dummy variables), and drainage basin area at the catchment and the station scales. We also analysed local species richness as a function of surface area of the drainage basin, regional species richness and square regional species richness. The last variable was used to model a saturation curve between local and regional species richness (CORNELL, 1985). The contribution of independent variables to the between-river and between-site variation in species richness was derived by stepwise multiple regression procedures (DRAPER and SMITH, 1981). At each iteration, only the variable showing the highest partial correlation with the dependent variable was included in the model only if its correlation was significant at the $5 \%$ level. All statistical analyses were performed using Systat 5 version 5.2.1., Evanston, IL for the Macintosh (WILKINSON, 1990).

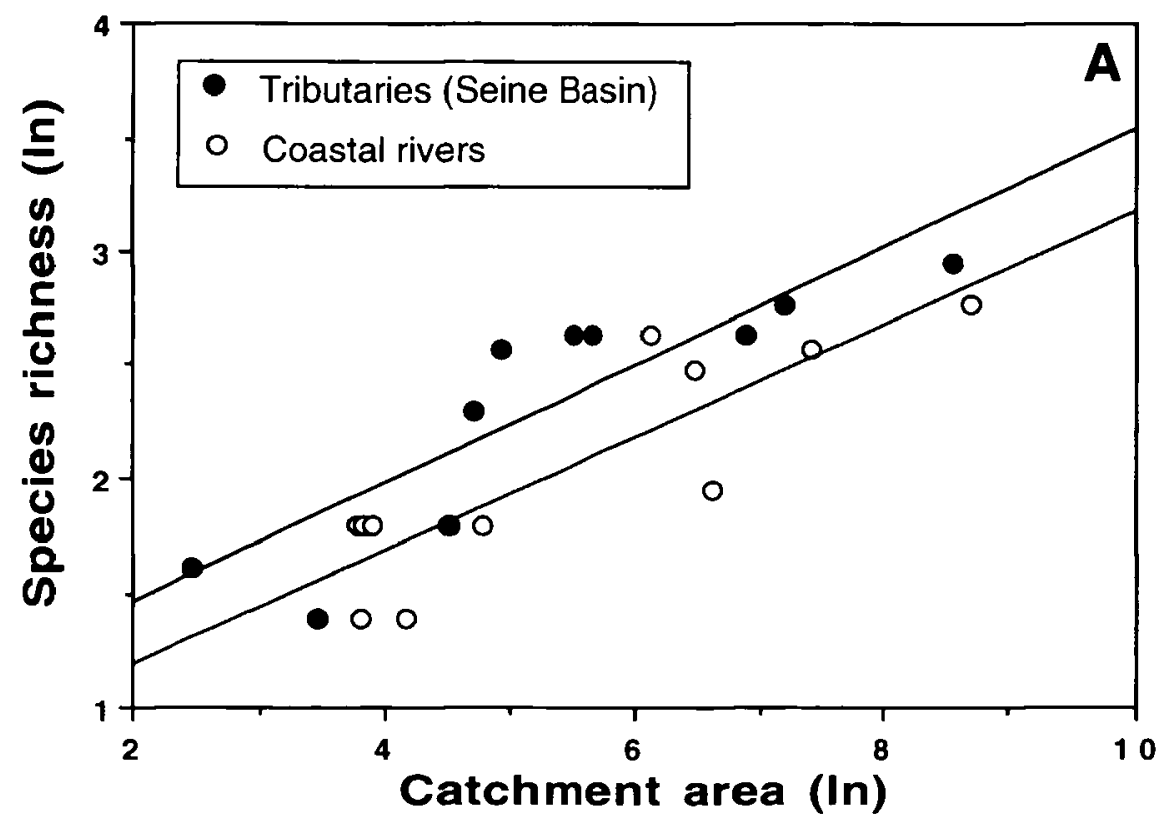

Figure 2 A

Relationship between species richness and total surface area of the drainage basin for tributaries and coastal rivers (regional scale).

Figure 2 A

Relation entre la richesse totale en espèces du cours d'eau et la taille de son bassin versant (échelle régionale). 


\section{RESULTS}

At the regional scale, species richness was positively correlated with total surface area of the drainage basin for both coastal rivers and tributaries (Figure 2A). The relationships obtained are :
Coastal rivers
(1) $\operatorname{lnSR}=0.249 \ln S+0.682 ; r^{2}=0.750 ; p=0.001$
Tributaries
(2) $\operatorname{lnSR}=0.260 \operatorname{lnS}+0.929 ; r^{2}=0.758 ; p=0.001$

where SR is species richness of freshwater fish and $S$ is the total surface area of the drainage basin in $\mathrm{km}^{2}$.

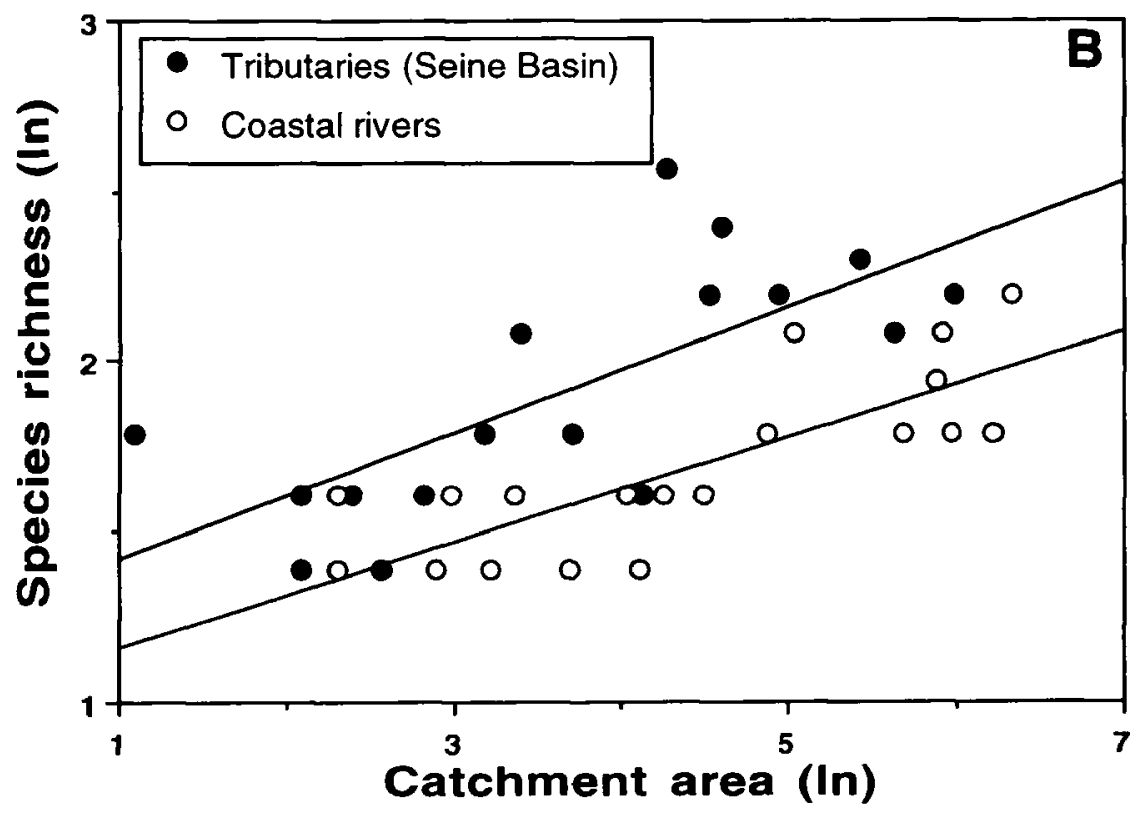

Figure 2 B

Relationship between species richness and surface area of the drainage basin for tributaries and coastal rivers (local scale).

Figure 2 B

Relation entre la richesse en espèces de la station et la superficie du bassin versant drainé (échelle locale).

The same study carried at station scale showed similar trends (Figure 2B), with the following relationships:
Coastal rivers
(1) $\ln S R=0.149 \ln S+1.036 ; r^{2}=0.594 ; p=0.001$
Tributaries
(2) $\operatorname{lnSR}=0.185 \operatorname{lnS}+1.235 ; r^{2}=0.519 ; p=0.001$

Our data clearly show that the species-area slopes are homogeneous among coastal rivers and tributaries at both scales (catchment scale : code (coastal river or tributary) -by-area interaction : $p=0.880$; station scale : code (coastal river or tributary)-by-area interaction : $p=$ 0.500 ). A model with area and code (tributaries or coastal rivers) fitted to these data (at both scales) indicated that both basin area and code explained significant amounts of variation in total fish numbers (Tables III, IV). 
Table III

(regional scale). Summary of multiple regression analysis of fish species richness (In scale) versus total surface area of the drainage basin and code (coastal rivers $=0$, tributaries $=1$ ). Also given are the slope coefficients, the standardized regression coefficients (magnitudes of standardized regression coefficients indicate the relative importance of each variable), and the probability associated with the partial $F$ of individual terms of the model. The final model is highly significant ( $\mathrm{dF}=2, \mathrm{R}^{2}=0.774, \mathrm{p}<0.001, \mathrm{n}=21$ ).

Tableau III

(échelle régionale). Résumé des résultats de la régression multiple de la richesse en espèces (In) en fonction de la superficie totale du bassin versant et du type de cours d'eau (fleuves côtiers = 0 ; affluents $=1)$. Le modèle final est hautement significatif $\left(d F=2, R^{2}=0.774, p<0.001, n=21\right)$.

\begin{tabular}{lccc}
\hline \multicolumn{1}{c}{ Variables } & $\begin{array}{c}\text { Slope } \\
\text { coefficient }\end{array}$ & $\begin{array}{c}\text { Standard } \\
\text { coefficient }\end{array}$ & $\begin{array}{c}\mathbf{P} \\
\text { (2 Tails) }\end{array}$ \\
Constant & 0.653 & 0.000 & 0.005 \\
$\begin{array}{l}\text { In (total surface area of } \\
\text { the drainage basin) }\end{array}$ & 0.254 & 0.831 & 0.0001 \\
Code & 0.305 & 0.297 & 0.016 \\
\hline
\end{tabular}

Table IV

(local scale). Summary of multiple regression analysis of fish species richness (In scale) versus surface area of the drainage basin and code (coastal rivers $=0$, tributaries $=1$ ). Also given are the slope coefficients, the standardized regression coefficients (magnitudes of standardized regression coefficients indicate the relative importance of each variable), and the probability associated with the partial $F$ of individual terms of the model. The final model is highly significant (dF $=2, R^{2}=0.602, p<0.001, n=37$ ).

\section{Tableau IV}

(échelle locale). Résumé des résultats de la régression multiple de la richesse en espèces (In) en fonction de la superficie du bassin versant drainé et du type de cours d'eau (fleuves côtiers $=0$; affluents $=1$ ). Le modèle final est hautement significatif $\left(d F=2, R^{2}=0.602, p<0.001, n=37\right.$ ).

\begin{tabular}{lccc}
\hline \multicolumn{1}{c}{ Variables } & $\begin{array}{c}\text { Slope } \\
\text { coefficient }\end{array}$ & $\begin{array}{c}\text { Standard } \\
\text { coefficient }\end{array}$ & $\begin{array}{c}\text { P } \\
\text { (2 Tails) }\end{array}$ \\
Constant & 0.960 & 0.000 & 0.0001 \\
$\begin{array}{l}\text { In (surface area of the } \\
\text { drainage basin) }\end{array}$ & 0.166 & 0.704 & 0.0001 \\
Code & 0.343 & 0.530 & 0.0001 \\
\hline
\end{tabular}

We can conclude that species richness in tributaries is always greater than in comparable coastal rivers whatever the scale of investigation (catchment or station scales). If, for the complete data set, we analyse the relationship between local species richness (station richness) and regional species richness (basin richness) after controlling for the upstream-downstream gradient (e.g. surface area of the drainage basin) the best fit is obtained with a linear model (Figure 3). This result demonstrates that local species richness does not strictly depend upon local conditions but also relies upon the regional pool of potential colonizers. 


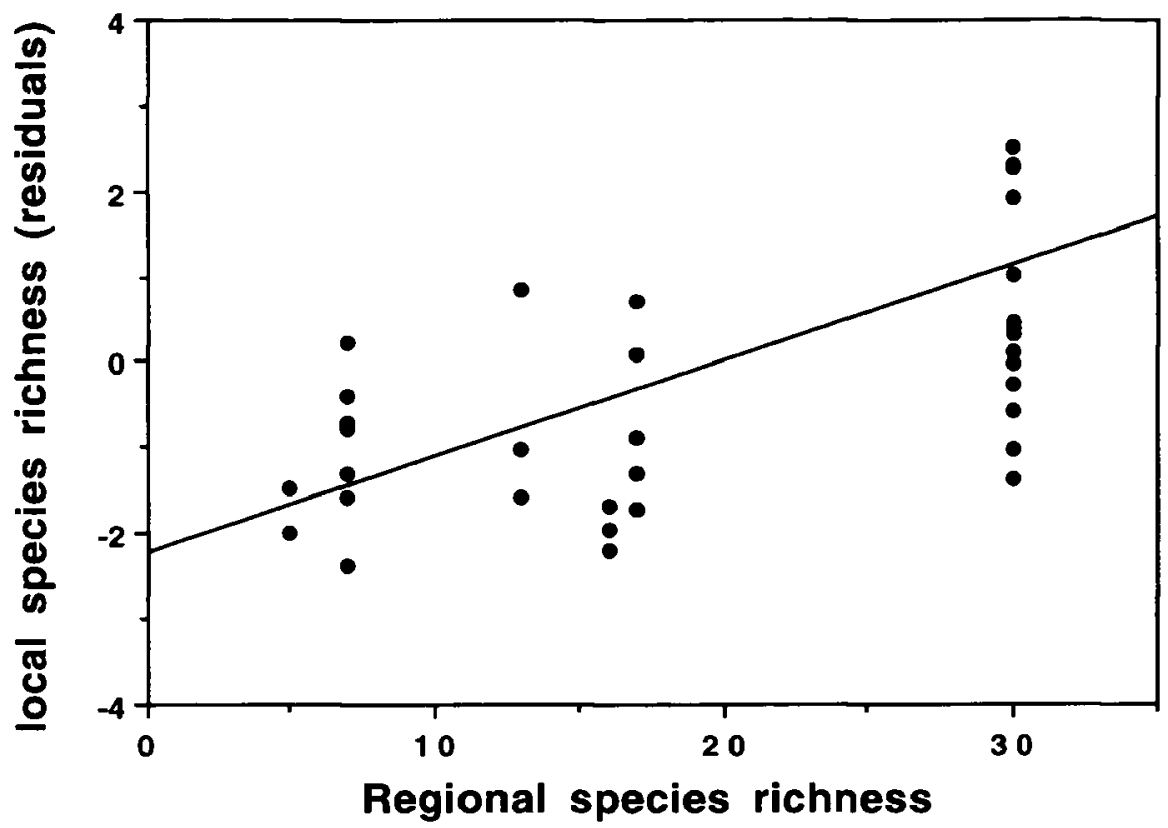

Figure 3

Relationship between local species richness (residuals) and regional species richness (tributaries and coastal rivers). The best fit is obtained with the following relationship : local species richness (residuals) $=-2.184+0.108 \times$ regional species richness $\left(R^{2}=0.313 ; p<0.01\right)$. $A$ second order does not contribute significantly to this equation when integrated $(p>0.05)$.

Figure 3

Relation entre les résidus de la richesse locale et la richesse régionale (affluents et fleuves côtiers). La relation est de type linéaire avec richesse locale (résidus) $=-\mathbf{2 . 1 8 4}+0.108 \times$ richesse régionale $\left(R^{2}=0.313 ; p<0.01\right)$. Le carré de la richesse régionale n'améliore pas significativement le modèle $(p>0.05)$.

\section{DISCUSSION}

Our results do not provide evidence supporting fish community saturation at the local scale, since local species richness increased with regional species richness. A previous study dealing with freshwater fish species richness at the local scale (station scale) corroborates these results (HUGUENY and PAUGY, 1995). This suggests that local fish communities in rivers are shaped by processes operating on a broader spatial scale, the most probable process being recolonization from neighbouring sites, which prevents long-term interspecific exclusion.

Knowledge of the degree of saturation of a community provides an important basis for understanding how the community reacts or will react to the introduction of new species. The data analysed here suggest that species introduction will have reduced short-term impact on local communities through species extinction. Thus, examination of this problem should be shifted from the local to the regional scale and from short-term to long-term effects. The comparison performed in the present study between tributaries and coastal rivers (fully isolated rivers) leads to the conclusion that species richness at the regional scale is regulated, in part, by an interplay between extinction and immigration and that there is no upper limit in species 
richness determined only by river size (and its correlates such as habitat diversity). As it is accepted that the richness of the West European freshwater fish fauna is low, partly due to historical processes (MAHON, 1984 ; MOYLE and HERBOLD, 1987 ; BANARESCU, 1989 ; WOOTTON, 1991 ; OBERDORFF et al., 1997), we can hypothesize that the insaturation pattern is likely to be true at the regional scale.

Management of species introduction is a difficult task because it is generally assumed that introduced species and target communities cannot be studied independently (LODGE, 1993) and that introduced species can have detrimental effects at different organization levels. However, intensive studies dealing with all these points are not cost effective and are difficult to implement, which makes them unlikely as attainable goals. Consequently, research priorities must be defined. Our data suggest that, for the rivers studied, local and probably regional communities are unsaturated and thus, that there is no need to devote great effort in assessing short-term community-wide consequences of species introduction because large detrimental effects are not expected at these scales. If, for example, we consider the total species richness within the Seine Basin, nineteen exotic species (about $40 \%$ of the total richness of the basin) are successfully established (BELLIARD, 1994) and have had to date, no clear negative effect on the survival of native species (e.g. no species extinction). Only diadromous species have been extirpated in recent years from the native fauna of the Seine Basin, presumably because of dams and water pollution. Thus, efforts should rather focus on other consequences of species introduction, such as the detrimental effects on some target species (e.g. endemic species), the introduction of parasites and diseases, the effects on population genetic structure, etc. (KOHLER and COURTENAY, 1986). For example, in the Euro-Mediterranean region, which is considered as a refuge zone with a high number of endemic species (BANARESCU, 1989), introductions are likely to reduce biodiversity on a global scale (world scale) should these endemic species become extinct.

\section{ACKNOWLEDGEMENTS}

This work was funded jointly by the Conseil Supérieur de la Pêche and by the Agence de l'Eau Seine-Normandie (subvention $n^{\circ} 1184$ ). We hasten to add, however, that this paper does not necessarily reflect the views of those organizations and no official endorsement should be inferred. We thank J.L. MAROUSÉ for help with drafting the figures and three anonymous referees for helpful comments on an earlier draft of the manuscript.

\section{REFERENCES}

ARTHINGTON A.H., 1991. Ecological and genetic impacts of introduced and translocated freshwater fishes in Australia. Can. J. Fish. Aquat. Sci., 48 (Suppl. 1), 33-43.

BALON E.K., 1974. Domestication of the carp Cyprinus carpio L. Toronto, Royal Ontario Museum, Life Science Misc. Publ., 37 p.

BANARESCU P., 1989. Zoogeography and history of the freshwater fish fauna of Europe. In HOLCIK J., The freshwater fishes of Europe, 89-107, Aula-Verlag, Wiesbaden.

BELLIARD J., 1994. Le peuplement ichtyologique du bassin de la Seine. Rôle et signification des échelles temporelles et spatiales. Thèse de Doctorat, Université Paris VI, $197 \mathrm{p}$.

BIANCO P.G., 1990. Vanishing freshwater fishes in Italy. J. Fish Biol., 37 (Suppl. A), 235-237.

BROWN J.H., 1989. Patterns, modes and extents of invasions by Vertebrates. In DRAKE J.A., MOONEY H.A., DI CASTRI F., GROVES R.H., KRUGER F.J., REJMÀNEK M., WILLIAMSON M., Biological invasion. A global perspective, 85-109, JOHN WILEY and SONS, Chichester. 
CESTAS, 1992. Transfert d'espèces. Publ. Assoc. Dev. Aquacult. Cestas. Bordeaux Aquaculture 92, Technical Session, Bordeaux, 31, 3-86.

CORNELL H.V., 1985. Local and regional richness of cynipine gall wasps on California oaks. Ecology, 66, 1247-1260.

DRAPER N.R., SMITH H., 1981. Applied regression analysis. Wiley, New York.

DUPIAS G., REY P., 1985. Document pour le zonage des régions phyto-écologiques. CNRS, Toulouse, 39 p. + carte.

ELVIRA B., 1995. Native and exotic freshwater fishes in Spanish river basins. Freshwater Biology, 33, 103-108.

HERBOLD B., MOYLE P.B., 1986. Introduced species and vacant niches. Am. Nat., 128, 751 760 .

HOLCIK J., 1991. Fish introductions in Europe with particular reference to its central and eastern part. Can. J. Fish. Aquat. Sci., 48 (Suppl. 1), 13-23.

HUGHES R.M., REXTAD E., BOND C.E., 1987. The relationship of aquatic ecoregions, river basin and ichtyogeographic regions of Oregon. Copeia, 2, 423-432.

HUGHES R.M., LARSEN D.P., 1988. Ecoregions : an approach to surface water protection. Journal of Water Pollution Control Federation, 60, 486-493.

HUGUENY B., 1989. West African rivers as biogeographic islands : species richness of fish communities. Oecologia, 79, 235-243.

HUGUENY B., PAUGY D., 1995. Unsatured fish communities in African rivers. Am. Nat., 146, 162-169.

KEITH P., ALLARDI J., MOUTOU B., 1992. Livre rouge des espèces menacées de poissons d'eau douce de France. Coll. Patrimoines Naturels, 10, S.F.F.M.N.H.N., C.S.P., CEMAGREF, Min. Env., Paris, 111 p.

KOHLER C.C., COURTENAY W.R., 1986. American Fisheries Society position on introductions of aquatic species. Fisheries, 11 (2), 39-42.

LODGE D.M., 1993. Biological invasion : lessons for ecology. Tree, 8, 133-137.

MC ARTHUR R.H., WILSON E.O., 1963. An equilibrium theory of insular zoogeography. Evolution, 17, 373-387.

MC ARTHUR R.H., WILSON E.O., 1967. The theory of island biogeography. Princeton University Press, Princeton, N.J.

MAHON R., 1984. Divergent structure in fish taxocenes of North temperate streams. Can. J. Fish. Aquat. Sci., 41, 330-350.

MOYLE P.B., LI H.W., BARTON B.A., 1986. The Frankenstein effect : impact of introduced fishes on native fishes in North America in STROUD R.H., Fish culture in fisheries management, 415-426, American Fisheries Society, Bethesda, MD.

MOYLE P.B., HERBOLD B., 1987. Life-history patterns and community structure in stream fishes of Western North America : comparisons with Eastern North America and Europe. In MATTHEWS W.J., HEINS D.C., Community and evolutionary ecology of North American stream fishes, 25-32, University of Oklahoma Press, Norman, London.

OBERDORFF T., GUÉGAN J.F., HUGUENY B., 1995. Global scale patterns of fish species richness in rivers. Ecography, 18, 345-352. 
OBERDORFF T., HUGUENY B., GUÉGAN J.F., 1997. Is there an influence of historical events on contemporary fish species richness in rivers ? Comparisons between Western Europe and North America. Journal of Biogeography (in press).

OMERNIK J.M., 1987. Ecoregions of the conterminious United States. Annals of the Association of America Geographers, 77, 118-128.

PIANKA E.R., 1983. Evolutionary ecology. HARPER and ROW, Publishers, New York, 416 p.

SOKAL R.R., ROHLF F.J., 1981. Biometry. FREEMAN W.H., San Francisco.

WELCOMME R.L., 1990. Status of fisheries in South American rivers. Interciencia, 15, 337-345.

WHITTIER T.R., HUGHES R.M., LARSEN D.P., 1988. Correspondence between ecoregions and spatial patterns in stream ecosystems in Oregon. Can. J. Fish. Aquat. Sci., 45, 12641278.

WILKINSON L., 1990. SYSTAT : The system for statistics. SYSTATS, Evanston, IL.

WOOTTON R.J., 1991. Ecology of Teleost fishes. Chapman and Hall Ltd., London. 